\title{
遠心式血液ポンプのための in vitro 抗血栓性試験 In vitro antithrombogenic test for rotary blood pump
}

○泊 陽輔、丸山 修*、杉山 大介、河村 洋、西田 正浩*、山根 隆志* 東京理科大学、*産業技術総合研究所

Yosuke Tomari, *Osamu Maruyama, Daisuke Sugiyama, Hiroshi KAWAMURA, *Masahiro Nishida, *Takashi Yamane Tokyo University of Science, *National Institute of Advanced Industrial Science and Technology

\section{1. 背景}

遠心式血液ポンプの開発において抗血栓性を付与すること は重要であり、ポンプの抗血栓性を生物学的に評価するため、 我々はヒツジを使った ex vivo 動物実験を利用している。動物 実験は大型動物実験施設及び手術を行う外科医を必要とする ため、実施できる研究機関は限られてしまう。従って、動物 実験を効率的に進める必要があり、試験血液ポンプが、少な くとも動物実験実施中は、生成した血栓により実験を中断す ることのないよう事前評価することが求められている。

\section{2. 目的}

遠心血液ポンプが目的期間の動物実験に耐えうる抗血栓 性を有することを生化学的に事前評価するために、閉回路を 利用した in vitro 抗血栓性試験法の確立を目的とした。

\section{3. 実験方法}

1）活性化凝固時間の制御

血液の抗凝固剂として臨床で一般的に使われているへパ リンとその中和剤であるプロタミンについて、ビーカー中 で両者を購入牛血に添加し、任意の活性化凝固時間 (ACT) となるように調整を行った。また、抗凝固郕としてクエン 酸ナトリウムと、その中和剤である塩化カルシウムでも同 様の調整を行い、両者の ACT 制御能について比較した。

\section{2) in vitro 抗血栓性試験}

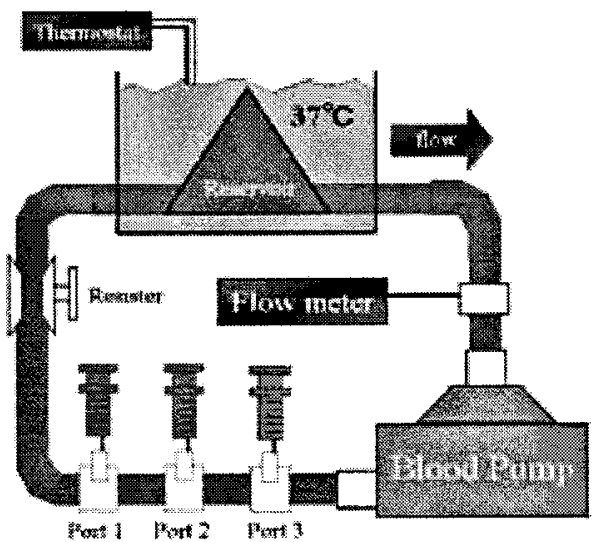

Fig.1 Mock circulation system for in vitro antithrombogenic testing

試験回路に血 液ポンプと血液 リザーバーを Fig.1のように 慗ぎ、クエン酸 ナトリウムと塩 化カルシウムを 使用して ACT を維持しながら、 購入牛血を循環 させる in vitro抗 血栓性試験を実 施した。実験条

件として、温度は $37^{\circ} \mathrm{C} 、$ 流量 $1.5 \mathrm{~L} / \mathrm{min} 、 \mathrm{ACT}=200 \mathrm{~s}$ で制御 しながら 2 時間循環させた後、運転を停止し、ポンプ内部 の血栓形成の有無を調べ 1 週間のヒツジを使用した ex vivo 動物実験（ACT;150-330s）の結果と比較した。使用した遠 心ポンプは産総研モノピボット型ポンプ DD3，DD6 および 動圧軸受型ポンプ HH7 の 3 種とした。

\section{4. 結果及び考察}

ヘパリンとプロタミンの組み合わせによる ACT 制御につ いては、プロタミンの過剩添加により、抗凝固剤の中和剤で あるにもかかわらず ACTが上昇する挙動を示した。一方、ク エン酸ナトリウムと塩化カルシウムについてはそれぞれの試 薬添加量の増加に伴って ACT は上昇、下降し ACT を任意に 制御できることが分かった。これらの結果よりクエン酸ナト

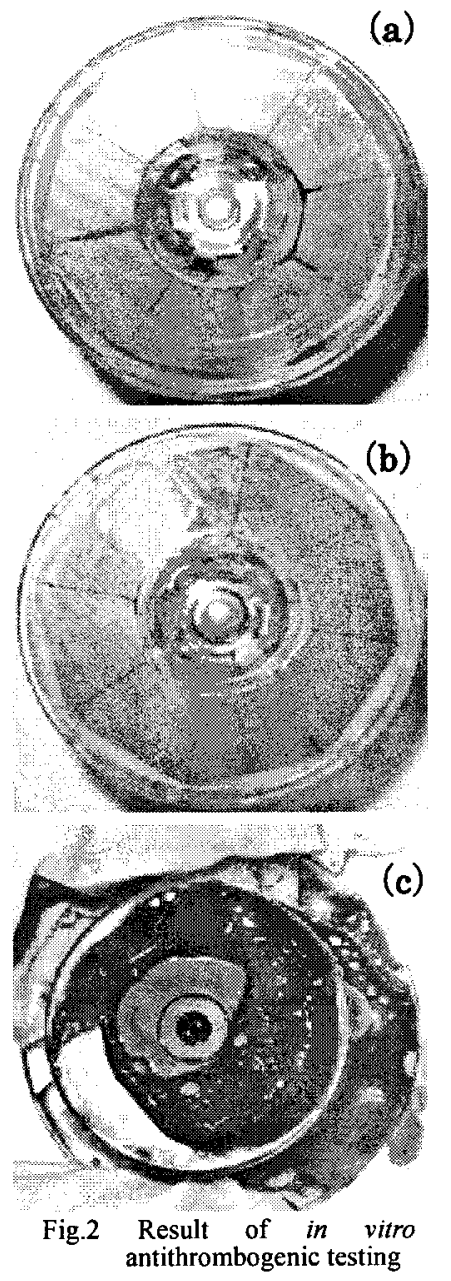

リウムと塩化カルシウム をin vitro 抗血栓性試験に 使用した。

In vitro 試験の結果を Fig.2 に示した。(a)のDD3 及び (b) のDD6にはポン プ内全ての部位において 血栓は生成していなかっ た。これらのポンプは、過 去に行った動物実験で血 栓形成が確認されたもの の、1 週間の実験継続に成 功している。これに対し (c) の HH7 はインペラ背 面全域で血栓が形成した。 $\mathrm{HH} 7$ と同型の $\mathrm{HH} 2$ で行っ た動物実験では実験開始 後、約 1.5 時間で血栓形成 による流量低下により実 験を中断した経緯がある。 これらの結果から現時点 では本研究の in vitro 抗血 栓性試験法による血栓の 有無は、上記実験条件によ る動物実験継続の可否を 推定できるものと期待し ている。

\section{5. 結論}

抗凝固剂クエン酸ナトリウムと中和剂塩化カルシウムを用 いて ACT200s, 2 時間の条件で in vitro 抗血栓性試験を行った 結果、動物実験の結果と相関を示しており、本条件による試 験法が 1 週間のex vivo 動物実験の継続可否を推定する事前評 価となる可能性が見出された。 